\title{
Taxonomic identity of the plant name Sanggisaeng
}

\section{Hyunchur SHIN* and Jongduk JUNG ${ }^{1}$}

\author{
Department of Life Sciences, Soonchunhyang University, Asan 31538, Korea \\ ${ }^{1}$ Northeastern Asia Biodiversity Institute, Seoul 05677, Korea \\ (Received 23 November 2018; Revised 20 December 2018; Accepted 24 December 2018)
}

\begin{abstract}
References in the modern Korean literature in this area to the Korean medicinal plant name written in Chinese script and expressed as Sanggisaeng have been extremely confusing. This name has been considered as six species, specifically Loranthus parasiticus, Loranthus tanakae, Taxillus yadoriki, Taxillus chinensis, Korthalsella japonica, and Viscum album var. coloratum. Recently, it was suggested that sanggisaeng is not distributed in Korea; however, the plant name Sanggisaeng recorded in old Korean literature sources, such as in the Hyang-yak-chaechwi-wol-lyeong, Hyang-yak-jib-seong-bang, and Dong-ui-bo-gam sources, among others, was identified using the name V. album var. coloratum, whereas in China, Sanggisaeng was referred to as T. sutchuenensis. The Hangeul name of Sanggisaeng had been Ppongnamugyeousali, but now the name Gyeousali is widely used.
\end{abstract}

Keywords: Hangeul plant name, Sanggisaeng, Viscum, Gyeousali, Ppongnamugyeousali

식물명 상기생(桑寄生)은 중국의 오래된 의약서인 『신 농본초경神農本草經』에 처음 나온다(Lee, 1975). 우리나라 에서는 채취할 수 있는 약재들을 사람들이 바르게 채취할 수 있도록 그 시기에 따라 월별로 약재명과 약재의 향명, 즉 우리말 이름을 기록하여 1431년 편찬된 『향약채취월 령鄕藥採取月令』에 “桑樹上冬乙沙里”라는 설명과 함께 처음으로 소개되었다. “桑樹上冬乙沙里”는 뽕나무(桑)에 서 자라는 겨우사리라는 의미로 보이는데, 손乙沙里는 옛 날식 우리말 표현으로, 손은 겨울 또는 겨우로, 沙里는 사리로 읽혔던 것으로 보인다. 이후 1433 년에 편찬된 『향 약집성방鄕藥集成方』과 1610 년 발간된 『동의보감東醫寶 鑑』에는 “상상기생(桑上寄生)”이라는 이름으로 나오는데, 『신농본초경』에 따르면 상상기생과 상기생은 같은 식물 이며(Ahn, 2012), 『향약집성방』에도 76권에서는 상기생으 로 표기되어 있으나, 80 권에서는 상상기생으로 표기되어 있다.

상기생이라는 식물명을 중국에서는 Taxillus sutchuenensis (Lecomte) Danser와 일치시키고 있으며, T. sutchuenensis를 포함하는 꼬리겨우살이과(Loranthaceae)를 桑寄生科로 부 르며, 꼬리겨우살이속(Loranthus)을 桑寄生屬으로 부르고 있다(Qiu et al., 2003). 그러나 우리나라에서는 2017년 11월 3일 일부개정된 대한민국약전외한약(생약)규격집(식품 의약품안전처고시 제2017-85호)에서 생약명 상기생을 국
내에는 분포하지 않은 “뽕나무겨우살이Loranthus parasiticus Merr. 또는 상기생 Loranthus chinensis (겨우살이 과 Loranthaceae)의 잎, 줄기, 가지"로 설명하고 있다. 즉, 상 기생이 L. parasiticus인지 L. chinensis Candolle (三Taxillus chinensis (Candolle) Danser)인지 또는 이 두 종 모두인지가 명확하지가 않다.

이를 반영하듯 우리나라에서는 상기생과 관련된 약효 연구는 외국에서 들여온 식물로 진행되고 있다(Kim et al., 2007; Roh et al., 2010; Kim et al., 2018). 그러나 과거 시장 에서 판매되는 상기생은 중국산 약재가 아니라 국내에서 자생하는 겨우살이(Viscum album L. var. coloratum (Kom.) Ohwi)로 조사되었고(Park, 1990), 겨우살이를 상기생과 대 비되는 이름으로 곡기생(槲寄生)으로 부르며, 상기생의 대용품으로 사용하나, 약효가 떨어지며 독성이 있는 것으 로 알려져 있다(Jang et al., 2007).

그러나 『향약채취월령』과 『향약집성방』에는 기본적으 로 우리나라에서 산출되는 약재를 이용하고 있고(Kim, 2006; Shin et al., 2017), 상기생이 이 문헌들에 등재되어 있 다면, 상기생도 국내에서 자생하는 식물의 약재명 또는 식물명이어야만 할 것이다. 그럼에도 대한민국약전외한 약(생약)규격집을 비롯하여 최근에 발간된 본초학 관련 도서에서는 중국에 분포하는 T. chinensis와 L. parasiticus 를 상기생으로 간주하고 있다(Shin, 2015). 또한 한국전통

\footnotetext{
*Author for correspondence: shinhy@sch.ac.kr
} 
Table 1. Korean and scientific names related Sanggisaeng in Korea and China.

\begin{tabular}{|c|c|c|c|c|}
\hline Taxa & $\begin{array}{c}\text { Genera of Vascular plants } \\
\text { of Korea }\end{array}$ & $\begin{array}{l}\text { The Korean Herbal } \\
\text { Pharmacopoeia }\end{array}$ & www.koreatk.com & Flora of China \\
\hline $\begin{array}{l}\text { Loranthus parasiticus } \\
\qquad(\equiv \text { Scurrula parasitica })\end{array}$ & & 뽕나무겨우살이 & 뽕나무겨우살이 & 홍화기생(紅花寄生) \\
\hline Loranthus tanakae & 꼬리겨우살이 & & 꼬리겨우살이 & 북상기생(北桑寄生) \\
\hline $\begin{array}{l}\text { Taxillus yadorikis } \\
\quad(\equiv \text { Loranthus yadoriki) }\end{array}$ & 참나무겨우살이 & & 참나무겨우살이 & \\
\hline $\begin{array}{l}\text { Taxillus chinensis } \\
\quad(\equiv \text { Loranthus chinensis })\end{array}$ & & 상기생 & 뽕나무겨우살이 & 광기생(广寄生) \\
\hline Korthalsella japonica & 동백나무겨우살이 & & 동백나무겨우살이 & 율기생(栗寄生) \\
\hline $\begin{array}{l}\text { Viscum album var. coloratum } \\
\qquad(\equiv \text { V. coloratum })\end{array}$ & 겨우살이 & & 겨우살이 & 곡기생(槲寄生) \\
\hline Taxillus sutchuensis & & & & 상기생(桑寄生) \\
\hline
\end{tabular}

지식포털(http://:www.koreatk.com)에서 상기생이라는 이 름이 중국에 분포하는 T. sutchuensis는 검색되지 않고 겨우 살이를 포함하여 6 종류의 식물을 지칭하는 것으로 검색 된다.

즉, 첫 번째로 뽕나무겨우살이(Loranthus parasiticus (L.) Merr.), 2번째는 꼬리겨우살이(L. tanakae Fr. \& Sav.), 3번째 는 참나무겨우살이(Taxillus yadoriki (Sieb. ex Maxim.) Danser.), 4번째는 뽕나무겨우살이(T. chinensis (DC) Danser.), 5번째는 동백나무겨우살이(Korthalsella japonica (Thunb.) Engl.), 그리고 마지막으로 겨우살이(Viscum album var. coloratum)가 상기생이라고 설명되어 있다. 이 중 꼬리겨우살이, 참나무겨우살이, 동백나무겨우살이와 겨 우살이는 국내에 자생하나, L. parasiticus와 T. chinensis라는 두 식물은 국내에서 자생하지 않고 있다(Kim et al., 2013) (Table 1).

흔히 식물명과 같이 사용되는 전통 약재명의 경우 정확 한 식물의 실체를 파악하고 사용하는 것이 기본일 것이나, 그럼에도 상기생의 경우, 정확한 실체가 규명되지 않은 상태에서 다양한 식물들을 전통지식이라는 이름으로 사 용하고 있어 문제가 될 수도 있을 것이다. 실제로 『향약집 성방』에는 “상기생이 아닌 다른 것을 먹어서는 안 되는데, 어떤 사람이 다른 나무에 기생한 겨우살이를 복용하고 한 달 후에 죽은 일도 있다(蓋不敢以㒚藥图人有人㒚以他木 寄生䢪之服 之逾月而死哀哉)”라고 되어 있다(Shin et al., 1998). 따라서 본 연구에서는 식물명 “상기생”의 분류학적 실체를 파악하고, 그에 따른 국명을 파악하고자 했다.

\section{재료 및 방법}

식물명 상기생의 분류학적 실체를 파악하기 위해 우리 나라 고전에서 이들의 용례를 검색했다. 중국의 경우 오 늘날 단 한 종, 즉 Taxillus sutchuenensis를 지칭하고 있어,
중국 고전에서 상기생의 용례는 검색하지 않았다. 단지 『향약집성방』에 있는 상기생에 대한 설명의 원저인 『본 초도경本草圖經』의 원문은 중국의 百家諸子(Chinese Text Project, 2018)에서 확인했다. 그리고 상기생이 우리나라에 서 자라는 식물이라고 설명되어 있는 『향약채취월령』은 고려대학교 해외한국학자료센터(Center for Overseas Resources on Korean Studies)에 소장중인 판본(청구기호 L174660)을 검토했고, 『향약집성방』은 한국학중앙연구원 에 소장된 판본과 『국역 향약집성방』(Shin et al., 1998)을, 『동의보감』의 경우『신편 대역 동의보감』(Anonymous, 2006) 내용을 검토했다. 이밖에 국사편찬위원회의 한국사 데이터베이스(Database in Korean History,), 한국고전번역 원의 한국고전종합DB (DB of Korean Classics), 그리고 조 선왕조실록(The Annals of the Joseon Dynasty) 등에서 상기 생이라는 식물명을 검색했다. 그리고 국내에서 발간된 각 종 도감류와 국명집을 비교 검토해서, 고전에 설명된 식 물들의 특성에 맞는 분류학적 실체를 파악하고, 이를 토 대로 학명과 국명을 조사했다.

\section{결과 및 고찰}

\section{고전에 기록된 상기생의 식물학적 특성}

『향약채취월령』과 『향약집성방』제 80 권「목부중품木 部上品」에서는 “상상기생”이 “師桑樹土冬乙沙里”라고 설 명되어 있는데, 뽕나무 위에 살아가는 겨우살이(冬乙沙里) 로 풀이된다. 그리고『향약집성방』『목부중품』에서는 “개 울가나 산골짜기에서 자라는 뽕나무에 붙어산다. 음력 3 월초에 줄기와 잎을 뜯어 그늘에서 말린다(生川谷桑樹上 三月三日採菜葉院乾)”라고 상기생을 설명하고 있다. 그 리고 “음력 3월초에 줄기와 잎을 뜨어 그늘에서 말린다" 는 설명은 『동의보감』에도 반복되어 있다.

그리고 『동의보감』에는 상기생을 “음력 3-4월에 황백색 
의 꽃이 피고, 6-7월에 열매가 익는데 색이 노랗고 팥알만 하다(三四月開花黃白色 六七月結實 黃色如小豆大)"라고 설명되어 있다. 이 설명은 『향약집성방』에서 인용한, 중국 송나라 시절 편찬된 『본초도경』의 설명과 같기 때문에, 중 국에 생육하는 상기생, 즉 T. sutchuenensis의 설명으로 추 정된다. 또한 『본초도경』에는 상기생의 채취 시기와 건조 방법을 “음력 3월 3일 줄기와 잎을 따서 그늘에 말린다(三 月三日探菜葉院乾)”라고 되어있어, 『향약집성방』에 있는 설명과 일치하다. 따라서 비록 『향약집성방』에 인용 문헌 표시는 없지만, 『향약집성방』에 있는 이 설명 역시 『본초 도경』에 있는 내용을 인용한 것으로 보이며, 『향약집성방』 $\lceil$ 목부중품」에 있는 상기생의 설명은 중국에 분포하는 $T$. sutchuenensis의 특성으로 보인다.

그러나 『향약집성방』제 76 권 「여러 약석을 포제하는 방 법諸品藥石炮製法度」 부분에는 상기생의 “잎은 꾸지뽕나 무와 비슷하며, 마디에서 대생하며, 뿌리는 나무에 박혀 있고, 얼음이 어는 겨울에도 시들지 않으며 여름에 작은 꽃이 핀다(其葉如柘對節而生, 根侵入樹柯上而生, 凌冬不 调, 夏生小花)"라고 설명되어 있다. 그러나 이런 설명이 『본초도경』에는 없어, 우리나라에 분포하는 상기생의 특 징을 설명하는 것으로 추정된다. 한편, 『향약채취월령』에 는 상기생이 음력 7월에 채취하는 약재로 설명되어 있어 『향약집성방』과는 차이를 보였다. 이상을 종합하면, 우리 나라에 분포하는 상기생은 상록성 기생식물로 잎은 대생 하며, 여름에 개화하는 식물로 판단된다.

\section{고전에 기록된 상기생의 국내 분포지}

상기생에 대해 최근 “우리나라 각지에 분포하나 뽕나무 겨우살이는 보기 힘들고 참나무겨우살이와 겨우살이 등 은 분포하다"라고 설명하고 있다(Shin, 2015). 그런데 여기 에서 말하는 뽕나무겨우살이는 T. chinensis와 L. parasiticus 두 종을 지칭하나(Shin, 2015), 이 두 종은 국내에 분포하지 않고 있다(Kim, 2007a, 2007b; Kim et al., 2013).

그럼에도 옛 문헌에는 상기생이 국내에도 분포함을 보 여주는 기록들이 있다. 『세종실록지리지世宗實錄地理志』 에는 충청도, 경상도, 황해도, 경상도의 토산물로 상기생 이 언급되어 있으며, 『조선왕조실록朝鮮王朝實錄』의「중 종실록中宗實錄」54권에는 상기생을 경상도, 전라도, 충 청도, 강원도, 황해도 등지에서 공급받았다고 기록되어 있다. 이밖에도「광해군일기光海君日記」 광해군 9년 6월 24일자에는 전라 좌수사 이홍립이 전남 순천 방답진 파태 도에서 자라는 상기생을 구해서 진상했다는 기록도 있다.

특히 『조선왕조실록』의「세종실록世宗實錄」세종 13 년 3 월 10 일 기사에는 “의원 김자견이 황해도 백령-대청 두 섬에서 나는 상기생 50 근을 채취하여 바쳤다. 본국에 예 전에는 상기생이 없던 것을 순심 별감 고전성이 순찰 발 견하여 비로소 이를 얻게 된 것이다(醫員金自堅探黄海道 白翎·大靑兩島所産桑寄生五十斤以進。本國舊無桑寄生,
自巡審別監高全性始得之.)”라고 기록되어 있다. 그리고 『신증동국여지승람新增東國舆地勝覽』제43권 황해도 편 에는 상기생이 대청도와 백령도 두 섬에서만 나는 토산물 로 기록되어 있고, 『조선왕조실록』「광해군일기」광해군 10 년 11 월 22 일자 기사에는 "백령도와 전라도와 경상도의 각 섬의 상기생을 각별히 배양하고 돌보도록 하라(向翎島 及兩南各島桑寄生, 各別培養看護事.)”는 내용도 들어있다.

이런 기록들은 중국에서 부르는 식물과는 다를 수도 있 는 상기생이 우리나라에도 분포하고 있음을 입증하는 것 으로 사료되는데, 우리나라에서는 상기생이 적어도 황해 도와 전라도에 자라고 있었던 것으로 추정된다. 단지 『승 정원일기承政院日記』 인조3년 8월 6일자에는 “남은 상기 생이 매우 적으니 월령(月令)에 구애되어 갖추지 못해서는 안 됩니다(且寄生遺在乏少, 不可拘於月令, 而不爲措備)” 라고 기록되어 있는 점으로 보아, 상기생의 수는 많지 않았 던 것으로 보인다. 또한 『향약채취월령』에 상기생을 7월 에 채취하라고 했으나, 이에 구애받지 말고 채취하라고 한 것으로 추정된다.

\section{상기생의 분류학적 실체}

우리나라 옛 문헌에 상기생이 기록되어 있는 점으로 보아, 중국에서 부르는 상기생과는 다름에도 불구하고 상기생으로 불렀던 식물이 우리나라에 분포한 것으로 간 주해야 할 것이다. 우리나라 옛 문헌에 기록된 식물명과 식물의 분류학적 실체가 중국과 다른 경우는 상당히 존 재하는데, 일례를 들면 식물명 송(松)을 들 수가 있다. 중 국에서는 흔히 油松(Pinus tabuliformis Carrière)을 松으로 간주하고 있으나(Pan, 2003), 이 식물은 우리나라에는 분 포하지 않는다. 대신 우리나라에서는 소나무(Pinus densiflora Siebold \& Zuccarini)를 흔히 송(松)으로 부르고 있는데, 1527 년 편찬된 한자 학습서인 『훈몽자회訓蒙字 會』에는 松을 “솔숑”으로 설명하면서 “松을 油松으로도 부르고 있다”고 설명했다. 소나무는 우리나라와 일본을 비롯하고 중국의 만주 지방에만 분포하고 있어(Sun, 2007), 우리나라에서 송(松)이라고 부르는 식물과 중국에 서 송(松)이라고 부르는 식물은 같은 한자명이지만 식물 의 실체는 다른 것이다. 상기생도 이런 사례와 비슷할 것 으로 추정된다.

『향약집성방』과 『동의보감』에는 상기생을 “뽕나무에 붙어산다(桑樹上)" 또는 “뽕나무에서 자란 것만을 약을 쓴다(惟桑上者入藥)”라고 설명하고 있어, 상기생은 뽕나 무에 기생하는 식물로 추정된다. 그러나 우리나라에 분포 하는 겨우살이 종류 중에 뽕나무를 숙주로 살아가는 식물 은 알려져 있지 않다. 우리나라에 분포하는 기생식물 종 류로는 참나무류, 버드나무류, 팽나무류, 배나무, 사시나 무, 황철나무 등에 기생하는 겨우살이(Viscum album var. coloratum) (Im, 1998), 참나무류와 밤나무에 기생하는 꼬 리겨우살이(Loranthus tanakae), 모밀잣밤나무, 동백나무, 
후박나무, 육박나무 등에 기생하는 참나무겨우살이 (Taxillus yadoriki) (Kim, 2007b), 그리고 동백나무, 우묵사 스레피나무, 사철나무, 모새나무 등에 기생하는 동백나무 겨우살이(Korthalsella japonica) (Kim, 2007a)가 있다.

이 가운데 동백나무겨우살이와 참나무겨우살이는 모 두 전남, 경남 그리고 제주 지역에만 분포하고 있어(Kim, $2007 \mathrm{a}, 2007 \mathrm{~b})$, 황해도 백령도와 대청도에 분포하는 것으 로 옛 문헌에 보고된 상기생은 아닐 것으로 간주된다. 그 리고 꼬리겨우살이는 백두대간을 따라 가리산, 가리왕산, 설악산, 속리산, 오대산, 소백산, 지리산 등지의 해발 $600-$ $900 \mathrm{~m}$ 에서 자생하는 것으로 알려져 있어(Lee et al., 2013) 옛 문헌에 상기생의 분포지로 보고된 황해도와 백령도에 는 자생하지 않은 것으로 추정된다. 또한 꼬리겨우살이의 경우 낙엽성이며, 꽃이 수상화서에 많이 달리기(Lee, 1996a) 때문에 상기생이 여름에 적은 꽃이 피며 상록성이 라는 『향약집성방』제76권「여러 약석을 포제하는 방법」 의 설명과 일치하지 않는다.

따라서 우리나라 옛 문헌에 기록된 상기생은 겨우살이 (Viscum album var. coloratum)로 추정되나, 단지 뽕나무에 서 기생하는 경우가 보고되지 않고 있다(Lee, 2009). 그러 나 뽕나무를 재배하면서 잎을 따기 편하도록 가지치기를 해서 자그마하게 키우기 때문에(Park, 2014) 겨우살이가 기생해서 살아갈 정도의 큰나무로 될 수 없었을 가능성은 있다. 실제로 1614 년에 편찬된 이수광의 『지봉유설芝峰 類說』에는 “상기생은 희귀한 식물인데, 수백 년 자란 오 래된 뽕나무 아니면 나지 않는다(桑寄生 稀貴之物 非數百 年老桑不产)”라고 설명이 되어있다.

그리고 1717 년에 편찬된 송시열의 『우암집尤萫集』제3 권에는 “상기생이라고 부르는 식물이 매우 드문데, 백 그 루 중 하나에도 기생하는 것이 없어 좌우로 찾아다녀도 구 할 수가 없다(所謂桑寄生, 此地桑樹甚柾, 百株無一寄生, 左右求之而不可得矣.)”라고 설명이 되어 있다. 뽕나무를 많이 재배했지만 잎과 가지를 누에를 키우려고 잘랐기 때 문에 겨우살이가 크게 자랄 정도로 크지 못했고, 그에 따 라 뽕나무에서 살아가는 상기생을 관찰할 수 없었던 상황 을 설명한 것으로 추정된다. 이를 입증하듯, 『조선왕조실 록』의「광해군일기」광해군 7년 1월 8일자 기사에는 “상기 생은 얻기 어려운 명약입니다. 팔도에 생산처가 없는데 오직 백령도에만 있습니다. 첨사 김기명이 관을 만든 목 재로 쓰고자 하여 그 늙은 뽕나무를 베려고 하자 주민들 이 일제히 호소하기까지 하였는데도 끝내 듣지 않고 모두 베었습니다. 대개 상기생은 수백 년 묵은 이 지역의 뽕나 무가 아니면 나지 않는데, 이로 인해 멸종되어 내국(內局) 에 올리는 것을 빠뜨리게 되었습니다(桑寄生乃難得之要 藥也. 八道無産處而只於白翎島有之. 薟使金基命欲爲棺 材, 伐其老桑, 居民等至於齊訴, 而終不聽, 盡伐之. 蓋寄生, 非此地數百年老桑不生而因此絶種, 以至關供於內局.)”라 는 보고도 기록되었다.

\section{상기생의 국명}

상기생의 우리말 이름은 『향약채취월령』에 이두 또는 향찰로 간주되는 桑樹上冬乙沙里가 시작일 것이다. 桑樹 上은 “뽕나무위”로, 손 沙里는 오늘날 “겨우사리”로 읽 을 수 있을 수 있으므로, 상기생을 우리나라에서는 뽕나 무위겨우살이로 불렀을 것으로 추정된다. 그리고 상기생 이 『동의보감』에는 쏭나모우희겨으사리로 표기되어 있으 며(Anonymous, 2006), 저자와 편찬년도가 미상인 『광재 물보廣才物譜』에는 “쏭나무겨우시리”로 되어있다(Chung et al., 1997). 즉, 상기생을 우리나라에서는 처음에는 뽕나 무위겨우살이로 부르다가, ‘위'가 빠지고 뽕나무겨우살 이라고 부르게 된 것으로 추정된다.

그러다 일제강점기인 1922년에 발간된 『An Enumeration of Plants Hitherto Known from Corea』에는 국명과 학명이 국 내에서는 처음으로 같이 표기되었는데, 오늘날 꼬리겨우 살이(Loranthus yadoriki Siebold)를 지칭하는 Taxillus yadoriki라는 학명에 상기생이라는 국명이 부여되었고, 겨 우살이(V. album var. coloratum)에는 율기생(栗寄生)이라 는 한자명과 겨우사리라는 국명이 부여되었다(Mori, 1922). 그리고 1932년 발간된 『土名對照滿鮮植物字彙』에 는 桑寄生이라는 한자명과 쏭나무겨우살기라는 한글명 이 Viscum album var. rubro-autrantiacum Makino라는 학명 에 부여되어 있었다(Murata, 1932). 이후 1937년에 발간된 『朝鮮植物鄉名集』는 Loranthus yadoriki에 참나무겨우사 리, Viscum coloratum (三Viscum album var. coloratum)에 겨 우사리라는 국명이 부여되었다(Chung et al., 1937). 단지 Viscum album var. rubro-autrantiacum는 열매가 붉게 익는 종류이나 열매가 성숙할 때까지 기본종과 구분이 되지 않 은 종류들로, 오늘날에는 $V$. album f. rubroautrantiacum (Makino) Ohwi라는 품종으로 부르거나(Kim, 2007b), 기본 종에 포함시키고 있다(Ohba, 2006).

Mori (1922)가 상기생이라는 이름을 꼬리겨우살이에 부 여하면서, 우리나라에서는 상기생으로 불렀던 겨우살이 에는, 겨우살이가 밤나무에 기생한다는 의미로, 율기생이 라는 이름을 붙였고, Chung et al. (1937)은 참나무 종류에 는 기생하지 않는 Loranthus yadoriki에 참나무겨우살이라 는 이름을 붙이면서, 우리나라에서 상기생으로 불렀던 겨 우살이에는 뽕나무를 의미하는 상(桑)이 빠지고 겨우살 이라는 이름만 남게 된 것으로 보인다. 일제강점기를 거 치면서 상기생이라는 이름, 즉 뽕나무겨우살이에서 겨우 살이로 변경된 것이다.

그리고 최근에는 상기생이 국내에는 자생하지 않은 것 으로 간주하면서, Loranthus parasiticus (Scurrula parasitica L., 중국명 紅花寄生)를 뽕나무겨우살이로, Loranthus chinensis (三Taxillus chinensis, 중국명 廣寄生)를 상기생으로 부르거나(식품의약품안전처고시 제2017-85 호), 또는 이 두 종이 서로 다른 속에 속하는 서로 다른 식 물임에도 불구하고 모두 뽕나무겨우살이, 즉 상기생으로 
부르고 있는 실정이다(Shin, 2015).

그러나 우리나라에서 발간된 식물 도감류나 명감류에 는 뽕나무겨우살이라는 이름이 없다(see Lee, 1996a, 1996b). 『향약채취월령』에서 桑樹上논 沙里라고 불렀던 상기생의 국명이, 『동의보감』에서는 한글로 쏭나모우희 겨으사리라고 표기되었다가 쏭나무겨우소리를 거쳐 쏭나 무겨우살기까지 왔으나, 이 이름은 이후 우리나라에서 발 간된 문헌에서 완전히 사라져버렸고, 그 대신 우리나라에 서는 자라지 않는 외국 식물에 뽕나무겨우살이라는 이름 이 붙어 있는 실정이다.

식물명 상기생의 적절한 국명과 학명은 1) 겨우살이를 기주식물에 따라 밤나무에 기생하는 종류는 율기생, 느릅 나무에 기생하는 종류는 유기생(榆寄生), 참나무에 기생 하는 종류는 곡기생 등으로 부르기도 하며(Murata, 1932), 2) 뽕나무보다는 밤나무, 느릅나무, 참나무 등에 기생하는 겨우살이 개체들이 더 흔히 발견되며, 3) 뽕나무겨우살이 라는 이름은 겨우살이 중 뽕나무에 기생하는 개체들만을 부르는 이름으로 겨우살이 전체를 대표할 수 있는 이름은 아니기 때문에, 학명은 Viscum album var. coloratum로, 국명 은 기주식물명이 포함되지 않은 겨우살이라는 이름으로 부르는 것이 타당할 것이다. 단지 옛 문헌에 나오며 약재 로 사용하는 뽕나무에 기생하는 개체들은 상기생 또는 뽕 나무겨우살이라는 약재명으로 구분해서 부르는 것이 필 요할 것으로 사료된다.

\section{Conflict of Interest}

The authors declare that there are no conflicts of interest.

\section{Literature Cited}

Ahn, D. K. (supervised). 2012. Hangeul Sinnongbonchogyung. Yisungdang, Seoul, 521 pp. (in Korean)

Anonymous, 2006. New Translation of Dongui Bogam (Principles and Practice of Eastern Medicine) Tangaekpyeon (Remedies). Buminmunhwasa, Seoul, 3987 pp. (in Korean)

Chung, T. H., B. S. Do, D. B. Lee and H. J. Lee. 1937. Botanical Names of Joseon. Society of History of Joseon, 222 pp. (in Korean)

Chung, Y. W., Y. P. Hong, K. H. Shim and K. K. Kim. 1997. Dictionary of Chinese terms in Later Chosen Dynasty. The Academy of Korean Studies, Seongnam, 694 pp. (in Korean)

Im, R. J. 1998. Flora Coreana, Vol. 5. The Science and Technology Publishing House, Pyongyang, 367 pp. (in Korean)

Jang, I.-S., C.-S. Yang, S.-D. Lee and C.-H. Han. 2007. A review of herbal medicinal products associated with toxic events in Korea. Journal of Korean Oriental Medicine 28: 1-10. (in Korean)
Kim, C.-S., S.-Y. Kim, B.-Y. Sun and J. S. Yi. 2013. A review of the taxonomic and ecological characteristics of Korean mistletoe types (Viscum, Korthalsella, Loranthus and Taxillus). Korean Journal of Plant Taxonomy 43: 81-89.

Kim, J.-K. 2006. An anaylsis of the cited literature on Hyangyakjibseongbang. Journal of the Institute of Bibliography 35: 183-229. (in Korean)

Kim, J.-K., Y.-C. Kim, J.-H. Lee and H.-J. Woo. 2007. The effects of Artemisiae Capillaris Herba, Curcumae Rhizoma, Loranthi Ramulus, and Orostachys Herba on expression of angiogenic factors in HepG2 cells. Korean Journal of Oriental Internal Medicine 28: 149-165. (in Korean)

Kim, J. S., A. Y. Lee, B. C. Moon, H. S. Kim, W. J. Kim, C. Kim, G. Choi, S.-H. Kim and J. M. Chun. 2018. Effects of aqueous extract from Taxillus chinensis on monosodium iodoacetateinduced osteoarthritis in rats. The Korea Journal of Herbology 33: 81-88. (in Korean)

Kim, Y. D. 2007a. Santalaceae. In The Genera of Vascular Plants of Korea. Park, C.-W. (ed.), Academy Publishing Co., Seoul. Pp. 653-655.

Kim, Y. D. 2007b. Loranthaceae. In The Genera of Vascular Plants of Korea. Park, C.-W. (ed.), Academy Publishing Co., Seoul. Pp. 656-657.

Lee, B.-D. 2009. Ecological environment of native habitats and host plant in Mistletoe (Viscum album var. coloratum). Korean Journal of Plant Resources 22: 389-393. (in Korean)

Lee, S. G., J. M. Chung, S. S. Kim, S. Y. Woo and H. D. Kang. 2013. Distribution, habitat characteristics and assessment of the conservation status of a rare mistletoe species, Loranthus tanakae (Loranthaceae) in Korea. Journal of Korean Society of Forest Science 102: 428-436. (in Korean)

Lee, S. I. 1975. Literature review about Sanggisaing. Jehan 2: $27-$ 31. (in Korean)

Lee, W. T. 1996a. Coloured Standard Illustrations of Korean Plants. Academy Publishing Co., Seoul, 624 pp. (in Korean)

Lee, W. T. 1996b. Lineamenta Florae Koreae. Academy Publishing Co., Seoul, 1688 pp. (in Korean)

Mori, T. 1922. An Enumeration of Plants Hitherto Known from Corea. The Government of Chosen, Seoul, 624 pp.

Murata, S. 1932. Botanical Dictionary of Korean and Manchuria. Mesirokaku Showing, Tokyo, 778 pp. (in Japanese)

Ohba, H. 2006. Loranthaceae. In Flora of Japan, Vol. IIa. Iwatsuki, K., D. E. Boufford and H. Ohba (eds.), Kodansha, Tokyo. Pp. 117-119.

Pan, B. J. 2003. Illustrated Plants of Sijing. Sanghai Books Publisher, Sanghai, 288 pp. (in Chinese)

Park, J.-H. 1990. Pharmacognostical studies on the Chinese crude drug "Sang Ki Saeng". Pusan Bulletin of Pharmaceutical Sci- 
ences 24: 54-60. (in Korean)

Park, S. J. 2014. Trees in the Palace. Nulwa, Seoul, 537 pp. (in Korean)

Qiu, H., H.-H. Chiu, H.-X. Kiu and M. G. Gibert. 2003. Loranthaceae. In Flora of China, Vol. 5. Ulmaceae through Basellaceae. Wu, Z. Y., P. H. Raven and D. Y. Hong (eds.), Science Press, Beijing and Missouri Botanical Garden Press, St. Louis, MO. Pp. 220-239.

Roh, S.-S., B.-I. Seo, Y.-D. Back and J.-H. Park. 2010. A philological study on poisoning of Taxillius Ramaulus. Journal of East-West Medicine 35: 39-42. (in Korean)
Shin, H., M. Nomura, I. K. Kim, H.-C. Ki and S.-J. Hong. 2017. Reexamination of plant name, Jingyo. Korean Journal of Plant Taxonomy 47: 328-335. (in Korean)

Shin, M. K. 2015. Clinical Traditional Herbalogy. Youngrimsa, Seoul. 956 pp. (in Korean)

Shin, M. K., K. Park and W. J. Maeng. 1998. Korean Translation Edition of Hyangyak jipseongbang $<$ III $>$ (translantion). Youngrimsa, Seoul, 2086 pp. (in Korean)

Sun, B. Y. 2007. Pinaceae. In The Genera of Vascular Plants of Korea. Park, C.-W. (ed.), Academy Publishing Co., Seoul. Pp. $118-125$.

\title{
식물명 상기생(桑寄生)의 분류학적 실체
}

\author{
신현철 - 정종덕 ${ }^{1}$ \\ 순천향대학교 생명시스템학과, ${ }^{1 ㄷ ㅗ ㅇ ㅂ ㅜ ㄱ ㅇ ㅏ ㅅ ㅐ ㅇ ㅁ ㅜ ㄹ ㄷ ㅏ ㅇ ㅑ ㅇ ㅅ ㅓ ㅇ ㅇ ㅕ ㄴ ㄱ ㅜ ㅅ ㅗ ~}$
}

적 요:『향약채취월령」과『동의보감」을 비롯한 우리나라 옛 문헌에 나오는 식물명 상기생(桑寄生)은 지금까 지 뽕나무겨우살이(Loranthus parasiticus), 꼬리겨우살이(Loranthus tanakae), 참나무겨우살이(Taxillus yadoriki), 뽕 나무겨우살이(Taxillus chinensis), 동백나무겨우살이(Korthalsella japonica), 그리고 겨우살이(Viscum album var. coloratum)로 알려져 왔다. 최근에는 상기생(桑寄生)이 국내에는 분포하지 않는다는 주장도 제기되었으 나, 옛 문헌에 기록된 상기생은 중국에서 부르는 상기생, 즉 Taxillus sutchuenensis과는 다른 겨우살이 $(V$. album var. coloratum)임이 확인되었다. 상기생을 뽕나무겨우살이라고 불렀으나, 최근에는 겨우살이로 부르고 있음이 확인되었다.

주요어: 한글 식물명, 상기생, 뽕나무겨우살이, 겨우살이 